\title{
Pertumbuhan dan produksi tanaman sawi Pakcoy (Brassica rapa l.) akibat dibudidayakan pada berbagai media tanam dan dosis pupuk organik
}

\author{
(Growth and production of mustard pakcoy (Brassica rapa 1.) due to cultivation in various \\ planting media and organic fertilizer dosage) \\ N.S. Damayanti, D.W. Widjajanto, dan Sutarno \\ Agroecotechnology, Faculty of Animal and Agricultural Sciences, Diponegoro University \\ Tembalang Campus, Semarang 50275 - Indonesia \\ Corresponding E-mail: nutrisridamayanti@gmail.com
}

\begin{abstract}
The experiment was aimed to determine the effect of various planting media and to find out the effective dose level of goat manure for growth and production of green mustard (Brassica rapa L.). A completely randomized factorial design $(5 \times 3)$ with 3 replications was used throughout the experiment. The study evaluated 2 treatment factors, the first factor was planting media (M) namely M0 = (soil), M1 $=($ soil + charcoal husk $)(1: 1), \mathrm{M} 2=($ soil + coconut fiber $)(1: 1)$. The second factor was the level of goat manure (D), namely (D0 = $0 \mathrm{~kg} \mathrm{~N} / \mathrm{ha}),(\mathrm{D} 1=125 \mathrm{~kg} \mathrm{~N} / \mathrm{ha}),(\mathrm{D} 2=150 \mathrm{~kg} \mathrm{~N} / \mathrm{ha}),(\mathrm{D} 3=175 \mathrm{~kg} \mathrm{~N} / \mathrm{ha})$, (D4 = $200 \mathrm{~kg} \mathrm{~N} / \mathrm{ha}$ ). Parameters observed were N uptake, number of leaves, fresh and dry weight of shoot and root. Collected data were analyzed using ANOVA and Duncan Test was employed for further analysis. Experiment showed that the treatment of planting media (M1) planting soil + rice husk charcoal and the use of a dose level treatment of goat manure (D4) $200 \mathrm{~kg} \mathrm{~N} / \mathrm{ha}$ as the best results of growth and production of pakcoy mustard (Brassica rapa L.). Overall treatment significantly affected the observed parameters, namely $\mathrm{N}$ uptake, leaf number, fresh and dry weight of shoot and root.
\end{abstract}

Keywords: planting media, dose of goat manure

\begin{abstract}
ABSTRAK
Tujuan penelitian adalah untuk mengetahui pengaruh pemberian berbagai media tanam serta mengetahui level dosis pupuk kandang kambing yang efektif untuk pertumbuhan dan produksi sawi pakcoy (Brassica rapa L.). Rancangan penelitian yang digunakan adalah rancangan acak lengkap pola faktorial (5x3) dengan 3 ulangan. Penelitian mengevaluasi 2 faktor perlakuan, yaitu faktor pertama perlakuan media tanam $(\mathrm{M})$ yaitu $\mathrm{M} 0=(\operatorname{tanah}), \mathrm{M} 1=(\operatorname{tanah}+\operatorname{arang}$ sekam $)(1: 1), \mathrm{M} 2=(\operatorname{tanah}+$ sabut kelapa) (1:1). Faktor kedua level dosis pupuk kandang kambing (D) yaitu (D0 $=0 \mathrm{~kg} \mathrm{~N} / \mathrm{ha}),(\mathrm{D} 1=125$ $\mathrm{kg} \mathrm{N} / \mathrm{ha}),(\mathrm{D} 2=150 \mathrm{~kg} \mathrm{~N} / \mathrm{ha}),(\mathrm{D} 3=175 \mathrm{~kg} \mathrm{~N} / \mathrm{ha}),(\mathrm{D} 4=200 \mathrm{~kg} \mathrm{~N} / \mathrm{ha})$. Parameter yang diamati adalah serapan N, jumlah daun, berat segar dan kering tajuk dan akar. Data yang diperoleh dianalisis dengan ANOVA dan pada perlakuan yang berbeda dilanjutkan dengan analisis lanjut Duncan test. Hasil penelitian menunjukkan bahwa perlakuan media tanam (M1) tanam tanah + arang sekam padi dan penggunaan perlakuan level dosis pupuk kandang kambing (D4) $200 \mathrm{~kg} \mathrm{~N} / \mathrm{ha}$ memberikan hasil terbaik untuk pertumbuhan dan produksi sawi pakcoy (Brassica rapa L.). Secara keseluruhan perlakuan berpengaruh nyata terhadap parameter yang diamati yaitu serapan $\mathrm{N}$, jumlah daun, berat segar dan kering tajuk dan akar.
\end{abstract}

Kata kunci : media tanam, dosis pupuk kandang kambing.

PENDAHULUAN

Pakchoy (Brassica rapa L.) adalah jenis tanaman sayur - sayuran termasuk dalam keluarga Brassicaceae. Sawi Pakcoy merupakan tanaman sayuran yang sangat dibutuhkan oleh manusia 
untuk memenuhi kebutuhan hidupnya. Hal ini disebabkan oleh karena kandungan gizi sawi pakcoy yang terdiri dari vitamin dan mineral sangat berguna untuk mempertahankan kesehatan dan mencegah penyakit. Di Indonesia, kebutuhan pasar sayuran terutama sawi pakcoy dari tahun ke tahun meningkat. Hal ini tercermin dari angka produksi sawi pakcoy berturut - turut pada tahun 2015 - 2017 mengalami fluktuasi yang dapat dilihat secara berturut - turut 565.636 ton (2015), 562.838 ton (2016), dan 583.770 ton (2017) (Direktorat Jendral Hortikultura, 2017).

Keterbatasan media tumbuh dan keberagaman komoditi dalam areal sempit, mengakibatkan produksi tanaman tidak optimal dan tidak berkelajutan. Keterbatasan media tanam yang berupa tanah dapat diantisipasi dengan memanfaatkan bahan organik dari hasil kegiatan yang dilakukan oleh masyarakat. Salah satu alternatif pemecahan masalah yaitu dengan mencari bahan - bahan selain tanah dan tanpa membutuhkan lahan yang luas untuk bercocok tanam. Menurut (Hadisuwito, 2015) menyatakan bahwa media tanam berfungsi sebagai tempat melekatnya akar, juga sebagai penyedia hara bagi tanaman. Menurut pendapat Hadi dkk., (2015) bahwa media tanam dapat diperbaiki dengan pemberian bahan organik seperti kompos, pupuk kandang atau bahan organik lain. Tanah yang berstruktur remah sangat baik untuk pertumbuhan dan perkembangan tanaman, karena di dalamnya mengandung bahan organik yang merupakan sumber ketersediaan hara bagi tanaman (Hernowo, 2010). Penggunaan limbah arang sekam dan sabut kelapa dapat dijadikan sebagai media tanam dan memiliki karakteristik sangat ringan, kasar sehingga sirkulasi udara tinggi karena banyak pori, kapasitas menahan air tinggi, warnanya yang hitam dapat mengabsorbsi sinar matahari secara efektif dan mempercepat perkecambahan. Sabut kelapa memiliki karakteristik mampu mengikat dan menyimpan air dengan kuat, serta mengandung unsur-unsur hara esensial, seperti kalsium (Ca), magnesium $(\mathrm{Mg})$, kalium $(\mathrm{K})$, natrium (N), dan fosfor (P) (Irawan, 2014). Pupuk kandang dapat bermanfaat bagi tanaman karena mengandung unsur kompleks yang dibutuhkan tanaman seperti $\mathrm{N}, \mathrm{P}, \mathrm{K}, \mathrm{Ca}, \mathrm{Mg}$ dan $\mathrm{S}$ (Mayadewi, 2017). Pupuk kandang kambing memiliki kelebihan diantaranya memiliki kandungan potasium yang cukup serta kandungan $\mathrm{N}$ yang tinggi (Suhesy dan Adriani, 2011).

Penelitian ini bertujuan untuk mengkaji adanya pengaruh pemberian media tanam arang sekam padi dan level dosis pupuk kandang kambing yang berbeda.

\section{MATERI DAN METODE}

\section{Materi}

Penelitian lapang telah dilaksanakan pada 17 April - 25 Mei 2018 di Screen House, dan Laboratorium Ekologi dan Produksi Tanaman, Fakultas Peternakan dan Pertanian, Universitas Diponegoro, Semarang, Provinsi Jawa Tengah. Lokasi penelitian berada pada posisi geografis $6^{\circ} 50^{\prime}-7^{\circ} 10^{\prime} \mathrm{LS}$ dan $109^{\circ} 35^{\prime}-110^{\circ} 50^{\prime}$ BT dengan ketinggian tempat 125 meter diatas permukaan laut (mdpl), dengan rata-rata suhu udara harian berkisar antara $26^{\circ} \mathrm{C}-32^{\circ} \mathrm{C}$ pada siang hari dan $25^{\circ} \mathrm{C}-28^{\circ} \mathrm{C}$ pada malam hari, dan kelembaban udara berkisar antara 65\%-96\%. Bahan - bahan yang digunakan adalah benih sawi pakcoy, tanah, arang sekam, sabut kelapa (cocopeat), polybag

Tabel 1. Serapan N Sawi Pakcoy (Brassica rapa L.)

\begin{tabular}{|c|c|c|c|c|c|c|}
\hline \multirow{3}{*}{ Media Tanam } & \multicolumn{5}{|c|}{ Dosis Pupuk Organik } & \multirow{3}{*}{ Rataan } \\
\hline & D0 & D1 & $\mathrm{D} 2$ & D3 & D4 & \\
\hline & \multicolumn{5}{|c|}{------------------------(g/tanaman)----------------------- } & \\
\hline M0 & $1,34^{\mathrm{i}}$ & $1,53^{\mathrm{h}}$ & $1,89^{\mathrm{g}}$ & $3,14^{\mathrm{e}}$ & $3,24^{\mathrm{d}}$ & $2,23^{\mathrm{b}}$ \\
\hline M1 & $2,72^{\mathrm{f}}$ & $3,15^{\mathrm{d}}$ & $3,73^{\mathrm{c}}$ & $4,53^{\mathrm{b}}$ & $6,54^{\mathrm{a}}$ & $4,13^{\mathrm{a}}$ \\
\hline M2 & $0,78^{\mathrm{k}}$ & $0,81^{\mathrm{jk}}$ & $0,92^{\mathrm{j}}$ & $1,28^{\mathrm{i}}$ & $1,52^{\mathrm{h}}$ & $1,06^{\mathrm{c}}$ \\
\hline Rataan & $1,6^{\mathrm{e}}$ & $1,8^{\mathrm{d}}$ & $2,2^{\mathrm{c}}$ & $3,0^{\mathrm{b}}$ & $3,8^{\mathrm{a}}$ & \\
\hline
\end{tabular}

Superskrip berbeda pada baris rataan,kolom rataan dan matrik interaksi menunjukkan perbedaan nyata $(\mathrm{p}<0,05)$ 
ukuran 40 x 40 (volume tanah $8 \mathrm{~kg}$ ) sebanyak 45 polybag, pestisida Decis 25EC, fungisida Dithane M-45 80 WP. Alat yang digunakan dalam penelitian adalah cangkul, meteran untuk, ember, handsprayer, gembor, kertas label, timbangan analitik, leaf area meter (LAM), $\mathrm{pH}$ meter, stirer dan shaker, kamera dan alat tulis.

\section{Metode}

Penelitian dilaksanakan dengan mempersiapkan bibit tanaman sawi pakcoy yang telah berumur 2 minggu. Persiapan media tanam dilakukan dengan pengambilan tanah di kebun percobaan Agrotechnopark Fakultas Peternakan dan Pertanian, Universitas Diponegoro, Semarang. Tanah diambil kemudian dikeringkan dan diayak dengan lolos saring $0,5 \times 0,5 \mathrm{~cm}$. Persiapan media tanam dilaksanakan dengan mempersiapkan media tanam (M0) tanah, (M1) tanah + arang sekam dengan takaran $1: 1$, (M2) tanah + sabut kelapa dengan takaran $1: 1$, media tanam diaduk sampai tercampur merata. Media tanam dimasukkan kedalam polybag dan ditimbang sebesar $8 \mathrm{~kg}$. Penyemaian benih sawi pakcoy (Brassica rapa L.) dilakukan pada media berupa kompos di tray semai. Setelah umur 2 minggu tanaman sudah muncul 3 - 4 daun, bibit pakcoy dipindahkan pada pot percobaan. Penanaman dilakukan dengan cara melubangi media tanam, lalu bibit tanaman pakcoy (Brassica rapa L.) pada pot percobaan ditransplanting ke media tanam di polybag yang sudah siap dengan ukuran 40 x $40 \mathrm{~cm}$. Pemilihan bibit yang dijadikan bahan tanam berukuran seragam, daun hijau dan tidak layu, tidak terkena penyakit dan tumbuh tegak.

Perawatan sawi pakcoy dilakukan dengan cara menyiram tanaman dilakukan pada pagi hari antara jam 05.00-07.00 dan sore hari antara jam 17.00-18.00. Pengendalian hama dan penyakit dilakukan dengan cara fisik dan mekanis. Pengendalian secara mekanis dilakukan dengan menggunakan insektisida Decis 25 EC dengan bahan aktif profenofos konsentrasi $1 \mathrm{ml} / \mathrm{l}$. Aplikasi insektisida dilakukan menggunakan handsprayer saat tanaman berumur 2 minggu setelah tanam.

Panen dilakukan pada umur 30 (HST). Sebelum pemanenan terlebih dahulu dilihat fisik tanaman seperti warna daun, bentuk daun, dan ukuran daun tanaman. Tanaman yang sudah siap dipanen umumnya daun dewasa berbentuk oval melebar, tangkai daun hijau cerah, serta tinggi relatif pendek antara 20-35 cm (Suhartini, 2015). Pemanenan dilakukan dengan cara mencabut seluruh tanaman dan memisahkan bagian tanaman dari tanah dan memisahkan menjadi bagian atas dan bawah.

Parameter yang diamati adalah serapan N, jumlah daun, berat segar dan kering tajuk dan akar.

\section{Rancangan Percobaan}

Rancangan yang digunakan dalam penelitian adalah Rancangan Acak Lengkap (RAL) pola faktorial ( $5 \times 3$ ), dengan 3 ulangan membentuk 45 unit percobaan. Faktor pertama (perlakuan media tanam) pada 3 taraf yaitu M0 (tanah), M1 (tanah + arang sekam padi 1:1), M2 (tanah + sabut kelapa (cocopeat) 1:1). Faktor kedua (level dosis nitrogen pada pupuk kambing) pada 5 taraf yaitu D0 $=0 \mathrm{~kg}$ $\mathrm{N} / \mathrm{ha}$ sebesar (0 g/tanaman), D1 $=125 \mathrm{~kg} \mathrm{~N} / \mathrm{ha}$ sebesar (196,5 g N/tanaman), D2 $=150 \mathrm{~kg} \mathrm{~N} / \mathrm{ha}$ sebesar (235,8 g N/tanaman), D3 $=175 \mathrm{~kg} \mathrm{~N} / \mathrm{ha}$ sebesar (275,1 g N/tanaman), D4 = $200 \mathrm{~kg} \mathrm{~N} / \mathrm{ha}$ sebesar (314,5 g N/tanaman). Data dianalisis

Tabel 2. Jumlah Daun Sawi Pakcoy (Brassica rapa L.)

\begin{tabular}{|c|c|c|c|c|c|c|}
\hline \multirow{3}{*}{ Media Tanam } & \multicolumn{5}{|c|}{ Dosis Pupuk Kandang Organik } & \multirow[b]{2}{*}{ Rataan } \\
\hline & D0 & D1 & $\mathrm{D} 2$ & D3 & D4 & \\
\hline & \multicolumn{5}{|c|}{ 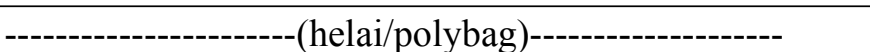 } & \\
\hline M0 & $16,3^{\mathrm{bc}}$ & $18,0^{\mathrm{ab}}$ & $16,0^{\mathrm{bc}}$ & $15,3^{\mathrm{bc}}$ & $15,0^{\text {bcd }}$ & $16,12^{\mathrm{b}}$ \\
\hline M1 & $17,3^{\mathrm{ab}}$ & $18,0^{\mathrm{ab}}$ & $19,7^{\mathrm{a}}$ & $18,0^{\mathrm{ab}}$ & $20,3^{\mathrm{a}}$ & $18,66^{\mathrm{a}}$ \\
\hline $\mathrm{M} 2$ & $9,7^{\mathrm{f}}$ & $11,3^{\mathrm{e}}$ & $11,7^{\mathrm{d}}$ & $13,7^{\mathrm{c}}$ & $14,7^{\text {bcd }}$ & $12,22^{\mathrm{c}}$ \\
\hline Rataan & $14,43^{b}$ & $15,77^{\mathrm{ab}}$ & $15,8^{\mathrm{ab}}$ & $15,67^{\mathrm{ab}}$ & $16,67^{\mathrm{a}}$ & \\
\hline
\end{tabular}

Superskrip berbeda pada baris rataan,kolom rataan dan matrik interaksi menunjukkan perbedaan nyata $(\mathrm{p}<0,05)$ 
ragam dan uji Duncan's Multiple Range Test (DMRT) pada taraf $\alpha=5 \%$.

\section{HASIL DAN PEMBAHASAN}

\section{Serapan N Sawi Pakcoy (Brassica rapa $\mathbf{L}$.)}

Hasil analisis ragam menunjukkan bahwa terdapat interaksi nyata $(\mathrm{P}<0,05)$ perlakuan media tanam dan level dosis pupuk organik terhadap serapan $\mathrm{N}$ pada sawi pakcoy. Perbedaan perlakuan media tanam dan level dosis pupuk organik berpengaruh nyata terhadap serapan $\mathrm{N}$ per tanaman. Berdasarkan Tabel 1 diketahui bahwa serapan $\mathrm{N}$ pada semua perlakuan media tanam M0 (tanah) memberikan hasil yang berbeda nyata pada D0 (0 kg N/ha), D1 (125 kg N/ha), D2 (150 $\mathrm{kg} \mathrm{N} / \mathrm{ha}), \mathrm{D} 3(175 \mathrm{~kg} \mathrm{~N} / \mathrm{ha})$, dan D4 (200 kg $\mathrm{N} /$ ha) memberikan hasil rata - rata sebesar $1,34 \mathrm{~g} /$ polybag, 1,53 g/polybag, 1,89 g/polybag, 3,14 g/polybag, 3,24 g/polybag. Hal tersebut menunjukkan pemberian perlakuan M0 memberikan hasil kurang optimal pada tanaman sawi pakcoy. Azizah et al., (2016) menyatakan bahwa rendahnya bahan organik dalam lahan pertanian dapat meningkatkan kekurangan unsur hara bagi tanaman sehingga produksi tanaman tidak optimal.

Perlakuan media tanam M1 (tanah + arang sekam) memberikan hasil yang berbeda nyata pada semua level dosis D0 (0 kg N/ha), D1 (125 $\mathrm{kg} \mathrm{N} / \mathrm{ha}), \mathrm{D} 2$ (150 kg N/ha), D3 (175 kg N/ha) dan D4 (200 kg N/ha) memberikan hasil berbeda nyata sebesar 2,72 g/polybag, 3,15 g/polybag, $3,73 \mathrm{~g} /$ polybag, 4,53 g/polybag, dan tertinggi 6,54 $\mathrm{g} /$ polybag. Hal tersebut menunjukkan pemberian media tanam arang sekam meningkatkan serapan $\mathrm{N}$ tanaman sawi pakcoy. Menurut pendapat
Benzon dan Velasco (2015) bahwa arang sekam merupakan media tanam yang bersifat mudah menyerap dan menyimpan air sehingga memiliki drainase yang baik.

Perlakuan media tanam M2 (tanah + sabut kelapa) dengan dosis D0 (0 kg N/ha), D1 (125 kg $\mathrm{N} / \mathrm{ha}), \mathrm{D} 2$ (150 kg N/ha) memberikan hasil tidak berbeda nyata dengan rata - rata $0,78 \mathrm{~g} /$ polybag, 0,81 g/polybag, dan 0,92 g/polybag, sedangkan pada level dosis pupuk D3 (175 kg N/ha) dan D4 (200 kg N/ha) memberikan hasil berbeda nyata dengan rata - rata 1,28 g/polybag, dan 1,52 g/polybag. Hal tersebut menunjukkan bahwa pemberian media tanam yang kurang tepat dapat menurunkan pertumbuhan tanaman. Hal ini sependapat dengan Fahmi (2013) bahwa zat tanin diketahui sebagai zat yang menghambat pertumbuhan tanaman.

\section{Jumlah Daun Sawi Pakcoy}

Hasil analisis ragam menunjukkan bahwa terdapat interaksi nyata $(\mathrm{P}<0,05)$ perlakuan media tanam dan dosis pupuk kandang organik terhadap jumlah daun pada sawi pakcoy (Tabel 2). Perbedaan perlakuan media tanam tidak berbeda nyata dan level dosis pupuk organik berpengaruh nyata terhadap jumlah daun. Berdasarkan Tabel 2 diketahui bahwa jumlah daun pada perlakuan media tanam M0 (tanah) dan D0 (0 kg N/ha) memberikan hasil sebesar 16,3 helai/polybag tidak berbeda nyata terhadap dosis D1 $(125 \mathrm{~kg} \mathrm{~N} /$ ha), D2 (150 kg N/ha), D3 (175 kg N/ha), dan D4 (200 kg N/ha) memberikan hasil sebesar 18,0 helai/polybag, 16,0 helai/polybag, 15,3 helai/polybag, 15,0 helai/polybag. Perlakuan media tanam M0 (tanah) memiliki hasil terkecil karena unsur hara tidak dapat mencukupi

Tabel 3. Berat Segar Tajuk Sawi Pakcoy (Brassica rapa L.)

\begin{tabular}{|c|c|c|c|c|c|c|}
\hline \multirow{3}{*}{ Media Tanam } & \multicolumn{5}{|c|}{ Dosis Pupuk Kandang Organik } & \multirow[b]{2}{*}{ Rataan } \\
\hline & D0 & D1 & D2 & D3 & $\mathrm{D} 4$ & \\
\hline & \multicolumn{5}{|c|}{ 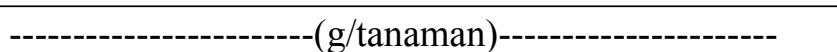 } & \\
\hline M0 & $520^{\mathrm{e}}$ & $528^{\mathrm{d}}$ & $535^{\mathrm{d}}$ & $553^{\mathrm{d}}$ & $588^{\mathrm{d}}$ & $545^{\mathrm{b}}$ \\
\hline M1 & $767^{\mathrm{c}}$ & $823^{\mathrm{c}}$ & $857^{\mathrm{c}}$ & $1.002^{\mathrm{b}}$ & $1.252^{\mathrm{a}}$ & $940^{\mathrm{a}}$ \\
\hline M2 & $107^{\mathrm{f}}$ & $195^{\mathrm{f}}$ & $320^{\mathrm{e}}$ & $340^{\mathrm{e}}$ & $393^{\mathrm{e}}$ & $271^{\mathrm{c}}$ \\
\hline Rataan & $464^{\mathrm{d}}$ & $515^{\text {cd }}$ & $571^{\mathrm{c}}$ & $632^{\mathrm{b}}$ & $744^{\mathrm{a}}$ & \\
\hline
\end{tabular}

Superskrip berbeda pada baris rataan,kolom rataan dan matrik interaksi menunjukkan perbedaan nyata $(\mathrm{p}<0,05)$ 
kebutuhan tanaman. Hal tersebut menunjukkan bahwa pada tanaman tidak tercukupi unsur haranya karena pemupukan hanya dilakukan sekali sehingga unsur hara yang diberikan tidak dapat mencukupi kebutuhan tanaman karena unsur $\mathrm{N}$ memiliki sifat yang mudah menguap dan tercuci. Menurut pendapat Silvester (2013) menyatakan bahwa pemberian pupuk kandang mampu menyediakan unsur hara yang tersedia untuk pembentukan pada bagian daun.

Perlakuan media tanam M1 (tanah + arang sekam) dengan semua level dosis D0 (0 kg N/ha), D1 (125 kg N/ha), D2 (150 kg N/ha), D3 (175 kg $\mathrm{N} / \mathrm{ha})$ dan D4 (200 kg N/ha) memberikan hasil tidak berbeda nyata yaitu sebesar 17,3 helai/polybag, $\quad 18,0 \quad$ helai/polybag, $\quad 19,7$ helai/polybag, 18,0 helai/polybag, dan tertinggi 20,3 helai/polybag. Terbukti dengan media arang sekam dan level dosis pupuk $200 \mathrm{~kg} \mathrm{~N} / \mathrm{ha}$ memberikan hasil jumlah daun paling baik. Penggunaan pupuk organik dengan dosis $200 \mathrm{~kg}$ $\mathrm{N} /$ ha mampu menyediakan unsur hara dengan baik untuk pertumbuhan daun pakcoy. Media tanam yang sesuai dengan tambahan suplai $\mathrm{N}$ mampu meningkatkan ketersediaan $\mathrm{N}$, sehingga pupuk fokus pada pertumbuhan vegetatif sawi pakcoy. Sesuai pendapat Abidin (2015) bahwa proses pembentukan daun tidak terlepas dari peranan unsur hara seperti nitrogen dan fosfor yang terdapat pada medium tanah dan dalam kondisi tersedia bagi tanaman. daun dan jumlah daun.

Perlakuan media tanam M2 (tanah + sabut kelapa) dengan dosis D0 (0 kg N/ha) dan D1 (125 $\mathrm{kg} \mathrm{N} / \mathrm{ha}$ ) memberikan hasil berbeda nyata dengan rata - rata 9,7 helai/polybag dan 11,3 helai/polybag, sedangkan pada level dosis pupuk D2 (150 kg N/ha), D3 (175 kg N/ha) dan D4 (200 $\mathrm{kg} \mathrm{N} / \mathrm{ha}$ ) memberikan hasil tidak berbeda nyata sebesar 11,7 helai/polybag, 13,7 helai/polybag, dan 14,7 helai/polybag. Unsur nitrogen yang tersedia dalam jumlah cukup dapat meningkatkan jumlah daun dan laju fotosintesis tanaman, sehingga daun dapat menghasilkan fotosintat dan energi yang lebih tinggi untuk pertumbuhan dan produksinya (Sari dkk., 2016).

\section{Berat Segar Tajuk Sawi Pakcoy}

Hasil analisis ragam menunjukkan bahwa terdapat interaksi nyata $(\mathrm{P}<0,05)$ perlakuan media tanam dan dosis pupuk kandang organik terhadap berat segar tajuk sawi pakcoy (Tabel 3). Perbedaan perlakuan media tanam dan level dosis pupuk organik berpengaruh nyata terhadap berat segar tajuk sawi pakcoy. Berdasarkan Tabel 3 diketahui bahwa berat segar tajuk sawi pakcoy pada perlakuan media tanam M0 (tanah) dan D0 $(0 \mathrm{~kg} \mathrm{~N} / \mathrm{ha})$ memberikan hasil rata - rata 520 $\mathrm{g}$ /polybag berbeda nyata terhadap level dosis pupuk D1 (125 kg N/ha), D2 (150 kg N/ha), D3 (175 kg N/ha), dan D4 (200 kg N/ha) memberikan hasil tidak berbeda nyata rata - rata sebesar $528 \mathrm{~g} /$ polybag, $535 \mathrm{~g} /$ polybag, $553 \mathrm{~g} /$ polybag, 588 g/polybag. Hal ini menunjukkan bahwa perlakuan M0 (tanah + arang sekam) memberikan media tanam yang baik dan ketersediaan $\mathrm{N}$ optimal. Azizah et al., (2016) menyatakan bahwa rendahnya bahan organik dalam lahan pertanian dapat meningkatkan kekurangan unsur hara bagi tanaman sehingga produksi tanaman tidak optimal. Rendahnya unsur hara $\mathrm{N}$ dan kandungan air pada kandungan tanah tidak dapat mempengaruhi produktivitas segar tajuk dengan baik.

Perlakuan media tanam M1 (tanah + arang

Tabel 4. Berat Segar Akar Sawi Pakcoy (Brassica rapa L.)

\begin{tabular}{|c|c|c|c|c|c|c|}
\hline \multirow{3}{*}{ Media Tanam } & \multicolumn{5}{|c|}{ Dosis Pupuk Kandang Organik } & \multirow[b]{2}{*}{ Rataan } \\
\hline & D0 & D1 & D2 & D3 & $\mathrm{D} 4$ & \\
\hline & \multicolumn{5}{|c|}{ 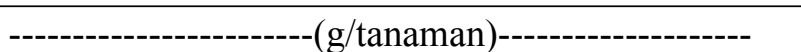 } & \\
\hline M0 & $43,80^{\mathrm{g}}$ & $48,16^{\mathrm{f}}$ & $51,62^{\circ}$ & $53,38^{\circ}$ & $57,27^{\mathrm{d}}$ & $50,85^{\mathrm{b}}$ \\
\hline M1 & $62,6 c^{d}$ & $65,49^{\mathrm{c}}$ & $64,93^{\circ}-(-2) \cdot(-1)$ & $76,7^{\mathrm{b}}$ & $86,51^{\mathrm{a}}$ & $71,25^{\mathrm{a}}$ \\
\hline M2 & $15,95^{\mathrm{h}}$ & $18,7^{\mathrm{h}}$ & $19,65^{\mathrm{h}}$ & $20,28^{\mathrm{h}}$ & $21,43^{\mathrm{h}}$ & $19,20^{c}$ \\
\hline Rataan & $40,78^{\mathrm{d}}$ & $44,12^{c}$ & $45,40^{\circ}$ & $50,12^{\mathrm{b}}$ & $55,07^{\mathrm{a}}$ & \\
\hline
\end{tabular}

Superskrip berbeda pada baris rataan,kolom rataan dan matrik interaksi menunjukkan perbedaan nyata $(\mathrm{p}<0,05)$ 
sekam) dengan level dosis D0 (0 kg N/ha), D1 (125 kg N/ha), D2 (150 kg N/ha) memberikan hasil tidak berbeda nyata dengan rata - rata $767 \mathrm{~g} /$ polybag, 823 g/polybag, 857 g/polybag, sedangkan D3 (175 kg N/ha) dan D4 (200 kg
(2016) bahwa pengunaan media tanam sabut kelapa harus dilakuan dengan dosis, metode dan cara aplikasi yang tepat.

\section{Berat Segar Akar Sawi Pakcoy}

Tabel 5. Berat Kering Tajuk Sawi Pakcoy (Brassica rapa L.)

\begin{tabular}{|c|c|c|c|c|c|c|}
\hline \multirow[t]{3}{*}{ Media Tanam } & \multicolumn{5}{|c|}{ Dosis Pupuk Kandang Organik } & \multirow[t]{2}{*}{ Rataan } \\
\hline & D0 & D1 & D2 & D3 & D4 & \\
\hline & \multicolumn{5}{|c|}{ 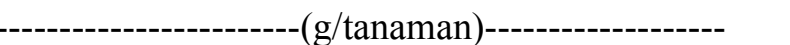 } & \\
\hline M0 & $59,8^{\mathrm{e}}$ & $59,5^{\mathrm{e}}$ & $59,7^{\mathrm{e}}$ & $64,6^{\mathrm{d}}$ & $69,5^{\mathrm{c}}$ & $62,6^{\mathrm{b}}$ \\
\hline M1 & $68,0^{\mathrm{c}}$ & $71,0^{\mathrm{c}}$ & $76,0^{\mathrm{b}}$ & $77,5^{\mathrm{b}}$ & $85,7^{\mathrm{a}}$ & $75,6^{\mathrm{a}}$ \\
\hline M2 & $28,8^{\mathrm{i}}$ & $35,1^{\mathrm{h}}$ & $36,4^{\mathrm{h}}$ & $39,8^{\mathrm{g}}$ & $44,0^{\mathrm{f}}$ & $36,8^{\mathrm{c}}$ \\
\hline Rataan & $52,2^{\mathrm{e}}$ & $55,2^{\mathrm{d}}$ & $57,4^{\mathrm{c}}$ & $60,6^{\mathrm{b}}$ & $66,4^{\mathrm{a}}$ & \\
\hline
\end{tabular}

Superskrip berbeda pada baris rataan,kolom rataan dan matrik interaksi menunjukkan perbedaan nyata $(\mathrm{p}<0,05)$

$\mathrm{N} / \mathrm{ha}$ ) memberikan hasil berbeda nyata dengan rata - rata $1.002 \mathrm{~g} /$ polybag dan $1.252 \mathrm{~g} /$ polybag. Hal ini menunjukkan bahwa perlakuan M1 (tanah + arang sekam) memberikan media tanam yang baik dan ketersediaan $\mathrm{N}$ optimal. Arang sekam berpengaruh terhadap pertumbuhan dan produksi tanaman, dengan hasil produksi hijauan segar tercapai paling tinggi. Sesuai pendapat Livy Winata (2017) bahwa tingginya unsur hara $\mathrm{N}$ dan kandungan air pada tanah dapat mempengaruhi produktivitas segar tajuk. Aplikasi unsur hara $\mathrm{N}$ pada dosis yang tepat akan meningkatkan pertumbuhan tanaman, meningkatkan metabolism tanaman, pembentukan protein, karbohidrat, akibatnya pertumbuhan dan produksi tanaman meningkat (Marlina et al., 2014).

Perlakuan media tanam M2 (tanah + sabut kelapa) dengan dosis D0 (0 kg N/ha) dan D1 (125 $\mathrm{kg} \mathrm{N} / \mathrm{ha}$ ) yaitu dengan rata - rata $107 \mathrm{~g} / \mathrm{polybag}$, $195 \mathrm{~g} /$ polybag memberikan hasil berbeda nyata dengan dosis pupuk D2 (150 kg N/ha), D3 (175 kg $\mathrm{N} / \mathrm{ha}$ ) dan D4 (200 kg N/ha) yaitu dengan rata rata $320 \mathrm{~g} /$ polybag, $340 \mathrm{~g} /$ polybag, $393 \mathrm{~g} /$ polybag. Hal ini menunjukkan bahwa perlakuan M2 (tanah + sabut kelapa) memberikan media tanam yang kurang tepat antara media tanam sabut kelapa dan dosis pupuk kandang kambing. Bernas et al., (2012) menambahkan bahwa serapan pupuk organik lambat pada media tanam sabut kelapa. Hal ini sesuai dengan pendapat Azizah et al.,
Hasil analisis ragam menunjukkan bahwa terdapat interaksi nyata $(\mathrm{P}<0,05)$ perlakuan media tanam dan dosis pupuk kandang organik terhadap berat segar akar sawi pakcoy (Tabel 4). Perbedaan perlakuan media tanam dan level dosis pupuk organik berpengaruh nyata terhadap berat segar akar sawi pakcoy. Berdasarkan Tabel 4 diketahui bahwa berat segar akar sawi pakcoy pada perlakuan media tanam M0 (tanah) dengan dosis D0 (0 kg N/ha) dan D4 (200 kg N/ha) memberikan hasil berbeda nyata yaitu sebesar $43,8 \mathrm{~g} /$ polybag dan 57,27 g/polybag, sedangkan pada D1 (125 kg $\mathrm{N} / \mathrm{ha})$, D2 (150 kg N/ha), D3 (175 kg N/ha) memberikan hasil yang tidak berbeda nyata sebesar 48,16 g/polybag, 51,62 g/polybag, 53,38 $\mathrm{g} /$ polybag. Hal ini menunjukkan bahwa pemberian dosis pupuk kandang kambing pada $200 \mathrm{~kg} \mathrm{~N} / \mathrm{ha}$ berpengaruh nyata terhadap pembentukan berat segar akar sawi pakcoy nyata lebih tinggi dibanding tanpa pemupukan. Hal ini sesuai dengan pendapat Rahmah et al., (2014) menambahkan bahwa pasokan nitrogen yang lebih besar cenderung meningkatkan auksin yang dapat menghambat berat segar pada akar, akan tetapi meningkatkan pertumbuhan produksi segar tajuk.

Perlakuan media tanam M1 (tanah + arang sekam) dengan level dosis D0 (0 kg N/ha), D3 (175 kg N/ha) dan D4 (200 kg N/ha) memberikan hasil yang berbeda nyata yaitu sebesar 62,6 g/polybag, 76,7 g/polybag, dan 86,51 g/polybag, 
Tabel 6. Berat Kering Akar Sawi Pakcoy (Brassica rapa L.)

\begin{tabular}{|c|c|c|c|c|c|c|}
\hline \multirow{3}{*}{ Media Tanam } & \multicolumn{5}{|c|}{ Dosis Pupuk Kandang Organik } & \multirow{3}{*}{ Rataan } \\
\hline & D0 & D1 & $\mathrm{D} 2$ & D3 & D4 & \\
\hline & \multicolumn{5}{|c|}{ 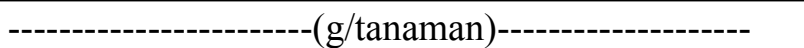 } & \\
\hline M0 & 4,10 & 3,79 & 5,86 & 5,06 & 4,02 & $4,57^{\mathrm{b}}$ \\
\hline M1 & 4,53 & 4,86 & 5,76 & 6,37 & 9,26 & $6,16^{\mathrm{a}}$ \\
\hline M2 & 1,61 & 2,78 & 1,49 & 3,82 & 4,31 & $2,80^{\mathrm{c}}$ \\
\hline Rataan & $3,41^{\mathrm{b}}$ & $3,81^{\mathrm{b}}$ & $4,37^{\mathrm{ab}}$ & $5,08^{\mathrm{ab}}$ & $5,86^{\mathrm{a}}$ & \\
\hline
\end{tabular}

Superskrip berbeda pada baris rataan,kolom rataan dan matrik interaksi menunjukkan perbedaan nyata $(\mathrm{p}<0,05)$

sementara pada level dosis pupuk D1 dan D2 memberikan hasil yang tidak berbeda nyata yaitu sebesar 65,49 dan 64,93. Hal ini menunjukkan bahwa perlakuan media tanam arang sekam dengan penambahan pupuk $\mathrm{N}$ sebesar $200 \mathrm{~kg} \mathrm{~N} / \mathrm{ha}$ mampu memberikan dukungan yang baik bagi pertumbuhan tanaman. Hal ini terlihat dari produksi segar akar dan tajuk tanaman. Media tanam mampu memberikan dukungan terhadap pertumbuhan akar dengan baik. Pertumbuhan akar yang baik mampu berpengaruh terhadap penyerapan unsur hara. Menurut Nathania et al., (2012) bahwa berat segar akar erat hubungannya dengan pertumbuhan dan perkembangan akar di dalam tanah.

Perlakuan media tanam M2 (tanah + sabut kelapa) pada semua level dosis D0 (0 kg N/ha), D1 (125 kg N/ha), D2 (150 kg N/ha), D3 (175 kg $\mathrm{N} / \mathrm{ha})$ dan D4 (200 kg N/ha) memberikan hasil yang tidak berbeda nyata yaitu sebesar 15,95 g/polybag, 18,7 g/polybag, 19,65 g/polybag, 20,28 g/polybag, dan 21,43 g/polybag. Hal ini menunjukkan bahwa media tanam sabut kelapa dan level dosis pupuk kandang kambing kurang dapat memenuhi berat segar akar pada sawi pakcoy. Hal ini sesuai dengan pendapat Sutedjo (2010) bahwa tanaman tidak akan memberikan hasil yang maksimal apabila unsur hara yang diperlukan cukup.

\section{Berat Kering Tajuk Sawi Pakcoy}

Hasil analisis ragam menunjukkan bahwa terdapat interaksi nyata $(\mathrm{P}<0,05)$ perlakuan media tanam dan dosis pupuk kandang organik terhadap berat kering tajuk sawi pakcoy (Tabel 5). Perbedaan perlakuan media tanam dan level dosis pupuk organik berpengaruh nyata terhadap berat kering tajuk sawi pakcoy. Berdasarkan Tabel 5 diketahui bahwa berat kering tajuk sawi pakcoy pada perlakuan media tanam M0 (tanah) dengan dosis D0 (0 kg N/ha), D1 (125 kg N/ha), D2 (150 $\mathrm{kg} \mathrm{N} / \mathrm{ha}$ ) memberikan hasil tidak berbeda nyata yaitu sebesar 59,8 g/polybag, 59,5 g/polybag, 59,7 g/polybag, sementara pada level dosis D3 dan D4 memberikan hasil berbeda nyata yaitu sebesar $64,6 \mathrm{~g} /$ polybag dan $69,5 \mathrm{~g} /$ polybag. Hal ini menunjukkan bahwa pemberian pemberian level dosis pupuk kandang kambing kurang tepat. Tambunan et al., (2013) menyatakan bahwa kekurangan nitrogen akan menghambat pertumbuhan tanaman, tanaman menjadi kerdil dan produksi tajuk pada sawi rendah. Rukmana (2011) menambahkan bahwa bobot kering menunjukkan kemampuan tanaman dalam mengambil unsur hara dari media tanam untuk menunjang pertumbuhannya.

Berat kering tajuk pada perlakuan M1 (tanah + arang sekam) dengan D4 (200 kg N/ha), sawi pakcoy mempunyai rata - rata sebesar 85,7 $\mathrm{g} /$ polybag nyata lebih tinggi dibanding perlakuan lainnya, pada level dosis D0 (0 kg N/ha) dan D1 (125 kg N/ha) memberikan hasil tidak berbeda nyata yaitu sebesar 68,0 g/polybag, dan 71,0 $\mathrm{g} /$ polybag, sementara itu berbeda nyata dengan D2 dan D3 yang memberikan hasil tidak berbeda nyata yaitu sebesar 76,0 g/polybag dan 77,5 g/polybag. Hal ini menunjukkan bahwa perlakuan M1 (tanah + arang sekam) dengan D4 $(200 \mathrm{~kg}$ $\mathrm{N} / \mathrm{ha}$ ) memberikan media tanam yang paling baik dan ketersediaan kadar N optimal. Sesuai dengan pendapat Prasetya et al., (2015) bahwa unsur N sangat dibutuhkan tanaman terutama pada fase 
vegetatif karena berfungsi membantu pembentukan fotosintat yang digunakan dalam pembentukan sel, perpanjangan sel dan penebalan jaringan tanaman.

\section{Berat Kering Akar Sawi Pakcoy}

Hasil analisis ragam menunjukkan bahwa tidak terdapat interaksi nyata $(\mathrm{P}<0,05)$ perlakuan media tanam dan dosis pupuk kandang organik terhadap berat kering akar sawi pakcoy (Tabel 6). Perbedaan perlakuan media tanam memberikan hasil nyata dan level dosis pupuk organik memberikan hasil tidak nyata terhadap berat kering akar sawi pakcoy. Berdasarkan Tabel 6 diketahui bahwa berat kering akar sawi pakcoy pada perlakuan media tanam M1 (tanah + arang sekam) memberikan hasil berbeda nyata dibanding perlakuan lainnya dengan rata - rata berat kering akar sebesar 6,16 g/polybag, sementara itu M0 (tanah) dan M2 (tanah + sabut kelapa) memberikan hasil 4,57 g/polybag dan 2,80 g/polybag. Respon tiap tanaman terhadap media tanam dan pemberian pupuk berbeda-beda, bergantung pada susunan kimia senyawa dan spesies tanaman (Sarno, 2013).

Pemberian dosis pada semua perlakuan D0 (0 $\mathrm{kg} \mathrm{N} / \mathrm{ha}), \mathrm{D} 1$ (125 kg N/ha), D2 (150 kg N/ha), D3 (175 kg N/ha), dan D4 (200 kg N/ha) memberikan hasil tidak berbeda nyata yaitu dengan rata - rata sebesar 3,41 g/polybag, 3,81 g/polybag, 4,37 g/polybag, 5,08 g/polybag, 5,86 g/ polybag. Hal ini terlihat dari produksi bahan kering akar dan tajuk tanaman yang mampu. Media tanam mampu memberikan dukungan terhadap pertumbuhan akar dengan baik. Pertumbuhan akar yang baik mampu karena adanya pemupukan yang efektif. Sesuai dengan Erawan et al., (2013) bahwa pemberian pemupukan yang efektif dapat meningkatkan bahan kering pada akar, dikarenakan pupuk kandang kambing dapat meningkatkan kandungan unsur hara N, P dan K. Sarno (2013) menambahkan bahwa berat kering tanaman mencerminkan akumulasi senyawa-senyawa yang berhasil disintesis tanaman dari senyawa anorganik terutama air dan karbondioksida serta unsur hara yang telah diserap akar sehingga memberikan kontribusi terhadap pertambahan berat kering tanaman.

\section{KESIMPULAN}

Berdasarkan hasil penelitian dapat disimpulkan bahwa pemberian perlakuan media tanam tanah + arang sekam padi (M1) dan penggunaan perlakuan level dosis pupuk kandang kambing $200 \mathrm{~kg} \mathrm{~N} / \mathrm{ha}$ (D4) memberikan hasil lebih baik untuk pertumbuhan dan produksi sawi pakcoy (Brassica rapa L.). Secara keseluruhan perlakuan berpengaruh nyata terhadap parameter yang diamati yaitu serapan $\mathrm{N}$, jumlah daun, berat segar tajuk, berat segar akar, berat kering tajuk, berat kering akar.

\section{DAFTAR PUSTAKA}

Abdulah dan Soedarmanto. 2017. Pemanfaatan arang sekam untuk memperbaiki pertumbuhan tanaman TOGA pada media subsoil. Jurnal Silvikultur Tropika 1 (1) : 24-28.

Abidin. 2015. Pengaruh perlakuan kombinasi media terhadap pertumbuhan sawi pakchoy (Brassica rapa L.). Jurnal Silvikultur Tropika. 3 (2) : 81-84.

Azizah, N., G. Haryono dan Tujiyanta. 2016. Respon macam pupuk organik macam mulsa terhadap hasil tanaman sawi hijau (Brassica juncea L.) var. tosakan. Vigor Jurnal Ilmu Pertanian Tropika dan Subtropika. 1 (1) : 44-51.

Benzon, J.A. dan J.R. Velasco. 2015. Coconut production and utilization. philipine coconut research and development foundation, inc Amber Avenue, Metro Manila. Philipine. Studi netralisasi limbah serbuk sabut kelapa (Cocopeat) Sebagai Media Tanam. IPB. Bogor.

Erawan, D., W.O. Yani, dan A. Bahrun. 2013. Pertumbuhan dan hasil tanaman sawi (Brassica juncea L.) pada berbagai dosis pupuk urea. J. Agroteknos. 3 (1) : $19-25$.

Hadisuwito. 2015. Pengaruh perlakuan kombinasi media tanam terhadap pertumbuhan tanaman sawi (Brasicca juncea L.). Jurnal 
Silvikultur Tropika. 3 (2) : 81-84.

Hernowo. 2010. Pengaruh penambahan sekam bakar pada media tanam terhadap pertumbuhan dan produksi tanaman sawi (Brasicca juncea L.). e-journal WIDYA Kesehatan dan Lingkungan. 1 (1) : 12-17.

Irawan, A. dan Hidayah, H., N. 2014. Kesesuaian penggunaan cocopeat sebagai media sapih pada politube pada tanaman kubis (Brassica oleraceae L.) balai penelitian pertanian. Manado. 1 (2) : 73-76.

Irawati dan Z. Salamah. 2013. Pertumbuhan tanaman sawi (Brassica rapa L.) dengan pemberian pupuk organik berbahan dasar kotoran kelinci. J. Bioedukatika. 1 (1): 3-14.

Marlina, N., Rosmiah dan N. Gofar. 2014. Aplikasi jenis pupuk organik pada tanaman sawi (Brassica juncea L.). J. Klorofil. 9 (2) : 75-79.

Mayadewi. 2017. Pengaruh macam media dan berbagai pupuk kandang terhadap pertumbuhan dan hasil selada (Lactuca sativa L.) hidroponik. Jurnal Agronomika 9 (3) : 257-264.

Nathania, B., I.M. Sukewijaya dan N.W.S Sutari. 2012. Pengaruh aplikasi biourin gajah terhadap pertumbuhan dan hasil tanaman sawi hijau (Brassica juncea L.). E-Jurnal Agroekoteknologi Tropika. 1 (1) : 72-85.

Parnata, A.S. 2010. Pertumbuhan dan produksi dengan pupuk organik pada tanaman caisim (Brassica juncea L.). Agrobisnis. 1 (1) : $98-102$.

Perwitasari. 2012. Pengaruh pemberian media tanam dan pupuk organik terhadap pertumbuhan dan hasil tanaman caisim (Brassica juncea L.). Jurnal Agronobis. 1 (1) : 89-98.

Prasetya, B., S. Kurniawan dan M. Febrianingsih. 2015. Pengaruh dosis dan frekuensi pupuk cair terhadap serapan $\mathrm{N}$ dan pertumbuhan sawi (Brassica juncea L.) pada entisol. J. Agritek. 17 (5) : 1022-1029.

Rahmah, A., M. Izzati dan S. Parman. 2014. Pengaruh pupuk organik cair berbahan dasar jagung manis (Zea mays L. Var. Saccharata). terhadap pertumbuhan tanaman sawi putih (Brassica chinensis L.). Buletin Anatomi dan Fisiologi. 22 (1) : 6571.

Rukmana, 2011. Meningkatkan hasil panen dengan pupuk kandang kambing pada pertumbuhan dan hasil tanaman pakchoy (Brassica rapa L.). J. Produksi Tanaman. 4 (5) : 35-41.

Sarno, S. 2013. Pengaruh kombinasi NPK dan pupuk kandang terhadap sifat fisik tanah dan pertumbuhan serta produksi tanaman caisim. J. Tanah Trop. 14 (3) : 211-219.

Setyowati, N., U. Nurjanah dan Haryanti. 2015. Gulma tusuk konde (Wedelia trilobata) dan kirinyu (Chlomoleana odorata) sebagai pupuk organik pada sawi (Brassica chinensis L.). J. Akta Agrosia. 11 (1) : 4756.

Suhesy dan Adriani. 2011. Pupuk organik dan pupuk hayati. Balai Besar Penelitian dan Pengembangan Sumberdaya Lahan Pertanian. Jawa Barat.

Sutedjo. 2010. Pemanfaatan limbah serbuk gergaji dan arang sekam sebagai media sapih untuk Pakchoy (Brassica rapa L.) Jurnal Sylva Lestari 2 (3) : 49-58.

Winata, L. 2017. Effect of plant density and nitrogen fertilization on growth and quality of mustard greens plants. J. Agric. Sci. 6 (3) : 56-63.

Valentino I. N. 2012. Pengaruh perlakuan kombinasi media terhadap pertumbuhan Sawi (Brassica chinensis L.) Jurnal Silvikultur Tropika 3 (2) : 81-84. 